\title{
Anion Effect of Zinc Source on Chemically Deposited $\mathrm{ZnS}(\mathbf{0 , 0 H})$ Films
}

\author{
K. Ernits, K. Muska, M. Danilson, J. Raudoja, T. Varema, O. Volobujeva, and M. Altosaar \\ Department of Material Science, Tallinn University of Technology, Ehitajate tee 5, Tallinn 19086, Estonia \\ Correspondence should be addressed to K. Ernits, whiisu@msn.com
}

Received 19 August 2009; Accepted 2 December 2009

Recommended by Steven Suib

\begin{abstract}
The study on the anion effect of different $\mathrm{Zn}$ sources- $\mathrm{Zn}\left(\mathrm{CH}_{3} \mathrm{COO}\right)_{2}, \mathrm{ZnCl}_{2}, \mathrm{ZnI}_{2}, \mathrm{Zn}\left(\mathrm{NO}_{3}\right)_{2}$ and $\mathrm{ZnSO}_{4}$-on the chemical deposition of $\mathrm{ZnS}(\mathrm{O}, \mathrm{OH})$ films revealed that the growth rate and composition of the $\mathrm{ZnS}(\mathrm{O}, \mathrm{OH})$ layer depend on the instability constant $(\mathrm{pK})$ value of the corresponding $\mathrm{Zn}$-complex $\mathrm{Zn}(\mathrm{L})_{n}$ in the chemical bath solution. In the region of $\mathrm{pK}_{\mathrm{Zn}(\mathrm{NH} 3) 2+}>\mathrm{pK} \mathrm{Zn}(\mathrm{L}) n_{n}$ the $\mathrm{ZnS}(\mathrm{O}, \mathrm{OH})$ film's growth rate and $\mathrm{ZnS}$ concentration in films increased with the increasing pK value of the used $\mathrm{Zn}$ salt complex up to the $\mathrm{pK}$ value of the $\mathrm{Zn}\left[\mathrm{NH}_{3}\right]^{2+}$ complex and decreased in the region where $\mathrm{pK}_{\mathrm{Zn}(\mathrm{NH} 3) 2+}<\mathrm{pK}$ Zn(L)n . The band gap values (around $3.6 \mathrm{eV}$ in most cases) of deposited $\mathrm{ZnS}(\mathrm{O}, \mathrm{OH})$ films did not depend on the $\mathrm{Zn}$ precursor's instability constant, the $\mathrm{ZnS}(\mathrm{O}, \mathrm{OH})$ film from zinc nitrate containing bath has higher band gap energy $\left(E_{g}=3.8 \mathrm{eV}\right)$. The maximum efficiency of CISSe and CZTSSe monograin layer solar cells was gained with $\mathrm{ZnS}(\mathrm{O}, \mathrm{OH})$ buffer layer deposited from CBD solution containing $\mathrm{Zn}\left(\mathrm{CH}_{3} \mathrm{COO}\right)_{2}$ as $\mathrm{Zn}$ source, which provided the highest growth rate and $\mathrm{ZnS}$ concentration in the $\mathrm{ZnS}(\mathrm{O}, \mathrm{OH})$ film on glass substrates.
\end{abstract}

Copyright (C) $2009 \mathrm{~K}$. Ernits et al. This is an open access article distributed under the Creative Commons Attribution License, which permits unrestricted use, distribution, and reproduction in any medium, provided the original work is properly cited.

\section{Introduction}

$\mathrm{ZnS}$ is beside CdS the second most investigated buffer layer material for $\mathrm{CuInSe}_{2}$ (CISe) type solar cells. $\mathrm{ZnS}$ is an attractive material mainly because of its wide band gap of $3.7 \mathrm{eV}$ [1], which makes it more transparent in the short wavelength region between 350 and $550 \mathrm{~nm}$ compared to $\mathrm{CdS}$ with the band gap value of $2.4 \mathrm{eV}$ [1]. A chemical bath deposition (CBD) is the most commonly used process for ZnS buffer formation on the top of a CISe type absorber. So far, the highest demonstrated CBD- $\mathrm{ZnS} / \mathrm{Cu}(\mathrm{In}, \mathrm{Ga}) \mathrm{Se}_{2}$ (CIGSe) solar cell efficiency is $18.6 \%$ as reported by NREL [2], while the highest efficiency obtained with CdS is $19.9 \%$ [3]. The high-efficiency ZnS/CIGSe solar cells were prepared also by the Nakada process [4], where zinc sulphate was used as the zinc source, thiourea as the sulphur source and ammonia as the complexing agent.

The present work aimed to study the impact of $\mathrm{Zn}$ precursor anion on the CBD-ZnS film's growth rate and properties. There are only few papers in the literature where the influence of different anion types in the $\mathrm{ZnS}$ deposition solution on thin film parameters was studied [5-7]. Eshuis et al. [5] pointed out that the chemical nature of used anions controls the growth rate, and morphology of $\mathrm{ZnS}$ particles. Several authors have studied CdS films deposited from different cadmium salts in ammonia solutions [8-10] and $\mathrm{ZnO}$ deposition from different zinc sources [11] as well. A change in the electrical resistivity, growth rate and particle size of the films with changes in chemical nature of anions in chemical bath solution was detected, but those changes did not lead to the changes in efficiencies of CISe solar cells [9]. Khallaf et al. [8] found that higher values of instability constants of the different cadmium complexes in the deposition solution led to the thinner CdS films. As the deposited CBD-ZnS films contain in addition to $\mathrm{ZnS}$ also $\mathrm{Zn}(\mathrm{OH})_{2}$ and $\mathrm{ZnO}$, it is typical to mark them as $\mathrm{ZnS}(\mathrm{O}, \mathrm{OH})$. In this study CBD-ZnS films were deposited from different $\mathrm{Zn}$ sources. The growth rate of the films along with compositional and optical properties presented together with photovoltaic characteristics of $\mathrm{CuIn}(\mathrm{S}, \mathrm{Se})_{2}$ (CISSe), and $\mathrm{Cu}_{2} \mathrm{ZnSn}(\mathrm{S}, \mathrm{Se})_{4}$ (CZTSSe) monograin layer (MGL) solar cells with $\mathrm{CBD} \mathrm{ZnS}(\mathrm{O}, \mathrm{OH})$ buffer layers. 


\section{Experimental Details}

2.1. $\mathrm{ZnS}(\mathrm{O}, \mathrm{OH})$ Film Deposition and Characterization. $\mathrm{ZnS}(\mathrm{O}, \mathrm{OH})$ thin films were deposited on soda lime glass (SLG) substrates. Freshly prepared water solutions contained $0.32 \mathrm{M} \mathrm{SC}\left(\mathrm{NH}_{2}\right)_{2}$ (thiourea (TU), $7.5 \mathrm{M}$ ammonia and $0.16 \mathrm{M} Z n$ precursor salt: $\mathrm{Zn}\left(\mathrm{CH}_{3} \mathrm{COO}\right)_{2} \cdot 2 \mathrm{H}_{2} \mathrm{O}\left(\mathrm{Zn}(\mathrm{Ac})_{2}\right)$, $\mathrm{ZnCl}_{2}, \mathrm{ZnI}_{2}, \mathrm{Zn}\left(\mathrm{NO}_{3}\right)_{2} \cdot 4 \mathrm{H}_{2} \mathrm{O}, \mathrm{ZnSO}_{4} \cdot 7 \mathrm{H}_{2} \mathrm{O}$. SLG substrates were cleaned with concentrated $\mathrm{H}_{2} \mathrm{SO}_{4}$ and rinsed with deionized (DI, $18 \mathrm{M} \Omega \cdot \mathrm{cm}$ ) water. All the used chemicals were pro analysi grade from Merck. The CBD solutions were prepared by dissolution of the $\mathrm{Zn}$ salt and TU in DI water separately and the two solutions were mixed at $85^{\circ} \mathrm{C}$ by continuous stirring. After 5 minutes the $\mathrm{NH}_{3}$ solution was added and substrates were dipped into the bath solution. The deposition process was stopped after 30 minutes by lifting the substrates out of the CBD solution. The deposited films were annealed in a semi closed quartz tube in conditions of continuous vacuum pumping at $220^{\circ} \mathrm{C}$ for 10 minutes.

Scanning Electron Microscopy (HR-SEM Zeiss ULTRA 55) was used to measure the thickness of the films. Xray Photoelectron Spectroscopy (Kratos Axis Ultra DLD, monochromatic $\mathrm{Al} \mathrm{K} \alpha$ radiation) was used to determine the $\mathrm{Zn}: \mathrm{S}: \mathrm{O}$ concentrations ratio in the films. Spectrophotometer with an integrating sphere (Jasco V-670 UV-VIS-NIR) was used to measure the optical transmission and to determine the optical band gaps of the $\mathrm{ZnS}(\mathrm{O}, \mathrm{OH})$ films.

2.2. $\mathrm{CuIn}(\mathrm{Se}, \mathrm{S})_{2}$ and $\mathrm{Cu}_{2} \mathrm{ZnSn}(\mathrm{S}, \mathrm{Se})_{4}$ Solar Cell Preparation and Characterization. Monograin layer (MGL) CISSe and CZTSSe solar cells were prepared as published elsewhere $[12,13]$. CBDs $\mathrm{ZnS}(\mathrm{O}, \mathrm{OH})$ films were deposited on the CISSe and CZTSSe monograin membranes at the solution temperature of $85^{\circ} \mathrm{C}$ for 5 minutes.

Prepared solar cells were characterized by current-voltage measurements, which were carried out in the darkness and under illumination of $100 \mathrm{~mW} \mathrm{~cm}^{-2}$.

\section{Results and Discussion}

3.1. Chemical Route to $\mathrm{ZnS}(\mathrm{O}, \mathrm{OH})$ Deposition and the Anion Effect. In the chemical bath solution, Zn-salt molecules decompose to ions and $\mathrm{Zn}^{2+}$ can form different complexes as follows:

$$
\begin{aligned}
2 \mathrm{Zn}^{2+} & +2 \mathrm{SC}\left(\mathrm{NH}_{2}\right)_{2}+4 \mathrm{NH}_{3} \\
& \longleftrightarrow\left[\mathrm{Zn}\left(\mathrm{SC}\left(\mathrm{NH}_{2}\right)_{2}\right)_{2}\right]^{2+}+\left[\mathrm{Zn}\left(\mathrm{NH}_{3}\right)_{4}\right]^{2+} .
\end{aligned}
$$

We assume that the formation of solid (s) $\mathrm{ZnS}(\mathrm{O}, \mathrm{OH})$ results through the decomposition of the following complexes in aqua deposition solutions by (2) and (3) as

$$
\begin{aligned}
& {\left[\mathrm{Zn}\left(\mathrm{SC}\left(\mathrm{NH}_{2}\right)_{2}\right)_{2}\right]^{2+}+2 \mathrm{OH}^{-}} \\
& \quad \longrightarrow \mathrm{ZnS}(\mathrm{s})+\mathrm{CN}_{2} \mathrm{H}_{2}+\mathrm{SC}\left(\mathrm{NH}_{2}\right)_{2}+2 \mathrm{H}_{2} \mathrm{O} \\
& {\left[\mathrm{Zn}\left(\mathrm{NH}_{3}\right)_{4}\right]^{2+}+\mathrm{SC}\left(\mathrm{NH}_{2}\right)_{2}+2 \mathrm{OH}^{-}} \\
& \quad \longrightarrow \mathrm{ZnS}(\mathrm{s})+4 \mathrm{NH}_{3}+2 \mathrm{H}_{2} \mathrm{O}+\mathrm{CN}_{2} \mathrm{H}_{2}
\end{aligned}
$$

Simultaneously to $\mathrm{ZnS}$ formation, zinc hydroxide can form in the ammonia containing solution as follows:

$$
\mathrm{Zn}^{2+}+2 \mathrm{OH}^{-} \longrightarrow \mathrm{Zn}(\mathrm{OH})_{2}(\mathrm{~s}) .
$$

The deposited films were annealed in vacuum at $220^{\circ} \mathrm{C}$ for 10 minutes to dehydrate $\mathrm{Zn}(\mathrm{OH})_{2}$ (5):

$$
\mathrm{Zn}(\mathrm{OH})_{2} \longrightarrow \mathrm{ZnO}(\mathrm{s})+\mathrm{H}_{2} \mathrm{O} \quad\left(T=125^{\circ} \mathrm{C}\right) .
$$

(see [14]). The anions from the used zinc salts play a role in the growth of $\mathrm{ZnS}(\mathrm{O}, \mathrm{OH})$ films as additional complexing agents, forming $\mathrm{Zn}$ (Ligand) ${ }_{n}\left(\mathrm{Zn}(\mathrm{L})_{n}\right)$ complexes besides $\left[\mathrm{Zn}\left(\mathrm{NH}_{3}\right)_{4}\right]^{2+}$ and $\left[\mathrm{Zn}(\mathrm{OH})_{4}\right]^{2+}$ in the chemical bath solution. $\mathrm{Zn}(\mathrm{L})_{n}$ complexes have different instability constants according to the anions (see Table 1). The instability constants were calculated for poorly dissociating complexes only; therefore, the instability constant for $\mathrm{Zn}\left(\mathrm{NO}_{3}\right)_{2}$ is not given.

Square brackets in Table 1 imply the concentrations. A high value of the instability constant $p K_{1}$ shows that the complex ion is easily formed, therefore the $\mathrm{Zn}(\mathrm{L})_{1}$ complex with $\mathrm{OH}^{-}$ion is the most stable complex in the series.

\subsection{The Results of $\mathrm{ZnS}(\mathrm{O}, \mathrm{OH})$ Films Measurements}

3.2.1. The Cluster Size and Thickness of $\mathrm{ZnS}(\mathrm{O}, \mathrm{OH})$ Films. SEM micrographs (presented elsewhere [16]) revealed that change in zinc sources affects the size of $\mathrm{ZnS}(\mathrm{O}, \mathrm{OH})$ clusters and the film thickness grown on SLG. The $\mathrm{ZnS}(\mathrm{O}, \mathrm{OH})$ film thickness depending on the instability constant $p K_{n}$ values of corresponding complex ions is presented in Figure 1. The thickest films with the largest clusters grew from $\mathrm{Zn}(\mathrm{Ac})_{2}$ containing chemical solution. $\mathrm{ZnS}(\mathrm{O}, \mathrm{OH})$ films with the smallest clusters grew from $\mathrm{ZnCl}_{2}$ and $\mathrm{Zn}\left(\mathrm{NO}_{3}\right)_{2}$ containing solutions. $\mathrm{ZnS}(\mathrm{O}, \mathrm{OH})$ film thickness increases with the instability constant values in the region (a) where $\mathrm{pK}_{\mathrm{Zn}(\mathrm{NH} 3) 2+}>\mathrm{pK}_{\mathrm{Zn}(\mathrm{L}) n}$ and decreases after the $\mathrm{Zn}\left[\mathrm{NH}_{3}\right]^{2+}$ complex line.

3.2.2. The Composition of $\mathrm{ZnS}(\mathrm{O}, \mathrm{OH})$ Films. XPS compositional measurements revealed that the $\mathrm{ZnS}(\mathrm{O}, \mathrm{OH})$ films contain $\mathrm{Zn}(\mathrm{OH})_{2}$ and $\mathrm{ZnO}$ besides $\mathrm{ZnS}$. The concentration of $\mathrm{ZnS}$ in the $\mathrm{ZnS}(\mathrm{O}, \mathrm{OH})$ films is given in Figure 2 (black stars). The obtained results show that the content of $\mathrm{ZnS}$ in $\mathrm{ZnS}(\mathrm{O}, \mathrm{OH})$ film is dependent on the instability constant of the zinc precursor complex. The content of $\mathrm{ZnS}$ in the films increases with the value of instability constants of $\mathrm{Zn}[\mathrm{L}]_{n}$ complex in the region (a) and drops after the $\mathrm{Zn}\left[\mathrm{NH}_{3}\right]^{2+}$ complex line in region (b). This is the indication of low deposition rate of $\mathrm{ZnS}$ and high deposition rate of $\mathrm{Zn}(\mathrm{O}, \mathrm{OH})_{2}$ in the region (b) where $\mathrm{Zn}[\mathrm{L}]_{n}$ complex is stronger than $\mathrm{Zn}\left[\mathrm{NH}_{3}\right]^{2+}$ complex.

XPS measurements revealed detectable amounts (below 1 mole \%) of several impurities in $\mathrm{ZnS}(\mathrm{O}, \mathrm{OH})$ films from $\mathrm{Zn}\left(\mathrm{NO}_{3}\right)_{2}(\mathrm{Cl}), \mathrm{ZnI}_{2}(\mathrm{Cd}, \mathrm{Cl}, \mathrm{N})$, and $\mathrm{Zn}(\mathrm{Ac})_{2}(\mathrm{~N})$.

XPS measurements showed also that the annealing process in vacuum at $200^{\circ} \mathrm{C}$ for 10 minutes was not sufficient to dehydrate $\mathrm{Zn}(\mathrm{OH})_{2}$ completely. It was the most successful 
TABLE 1: Instability constants $\mathrm{pK}$ of $\mathrm{Zn}$ complexes [15].

\begin{tabular}{lcc}
\hline Decomplexation reactions of $\mathrm{Zn}(\mathrm{L})_{1}$ & $\begin{array}{c}\text { Calculation of equilibrium constant }\left(\mathrm{K}_{1}\right) \\
\text { for the reaction }\end{array}$ & $\begin{array}{c}\text { Instability constant of Zn complex ion } \\
\mathrm{pK}_{1}=-\log \mathrm{K}_{1}\left(\text { at } 25^{\circ} \mathrm{C}\right)\end{array}$ \\
\hline $\mathrm{Zn}(\mathrm{OH})^{+} \longleftrightarrow \mathrm{Zn}^{2+}+\mathrm{OH}$ & {$\left[\mathrm{Zn}^{2+}\right] \cdot\left[\mathrm{OH}^{-}\right] /\left[\mathrm{Zn}(\mathrm{OH})^{+}\right]$} & 4.4 \\
$\mathrm{Zn}\left(\mathrm{NH}_{3}\right)^{2+} \longleftrightarrow \mathrm{Zn}^{2+}+\mathrm{NH}_{3}$ & {$\left[\mathrm{Zn}^{2+}\right] \cdot\left[\mathrm{NH}_{3}\right] /\left[\mathrm{Zn}\left(\mathrm{NH}_{3}\right)^{2+}\right]$} & 2.2 \\
$\mathrm{Zn}(\mathrm{TU})^{2+} \longleftrightarrow \mathrm{Zn}^{2+}+\mathrm{TU}$ & {$\left[\mathrm{Zn}^{2+}\right] \cdot[\mathrm{TU}] /\left[\mathrm{Zn}(\mathrm{TU})^{2+}\right]$} & 0.5 \\
$\mathrm{Zn}\left(\mathrm{SO}_{4}\right)^{0} \longleftrightarrow \mathrm{Zn}^{2+}+\mathrm{SO}_{4}^{2-}$ & {$\left[\mathrm{Zn}^{2+}\right] \cdot\left[\mathrm{SO}_{4}^{2-}\right] /\left[\mathrm{Zn}\left(\mathrm{SO}_{4}\right)^{0}\right]$} & 2.3 \\
$\mathrm{Zn}(\mathrm{Ac})^{+} \longleftrightarrow \mathrm{Zn}^{2+}+\mathrm{Ac}^{-}$ & {$\left[\mathrm{Zn}^{2+}\right] \cdot\left[\mathrm{Ac}^{-}\right] /\left[\mathrm{Zn}(\mathrm{Ac})^{+}\right]$} & 1.6 \\
$\mathrm{Zn}(\mathrm{Cl})^{+} \longleftrightarrow \mathrm{Zn}^{2+}+\mathrm{CI}^{-}$ & {$\left[\mathrm{Zn}^{2+}\right] \cdot\left[\mathrm{Cl}^{-}\right] /\left[\mathrm{Zn}(\mathrm{Cl})^{-}\right]$} & -0.5 \\
$\mathrm{Zn}(\mathrm{I})^{+} \longleftrightarrow \mathrm{Zn}^{2+}+\mathrm{I}^{-}$ & {$\left[\mathrm{Zn}^{2+}\right] \cdot\left[\mathrm{I}^{-}\right] /\left[\mathrm{Zn}(\mathrm{l})^{-}\right]$} & -2.9 \\
$\mathrm{Zn}\left(\mathrm{NO}_{3}\right)_{2} \longleftrightarrow \mathrm{Zn}^{2+}+2 \mathrm{NO}_{3}^{-}$ & & Unstable compound \\
\hline
\end{tabular}

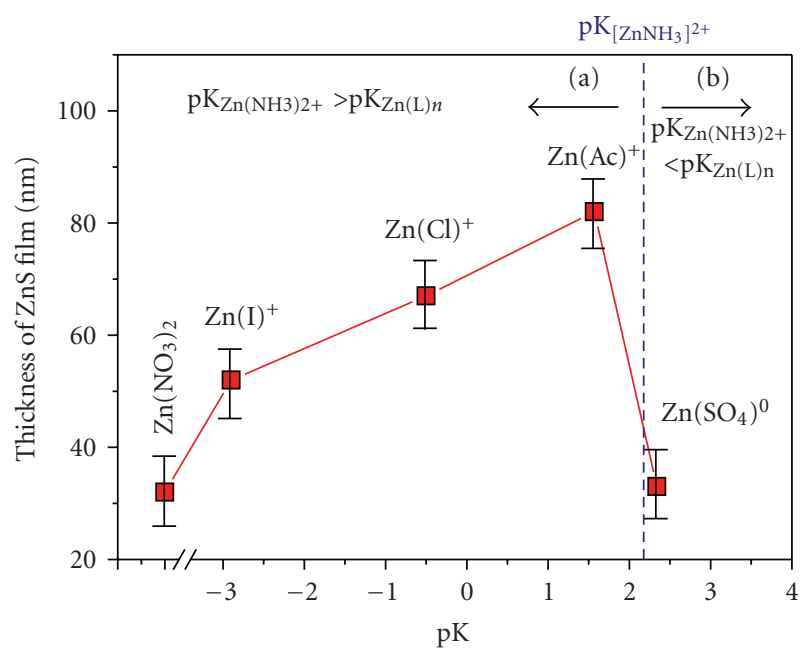

Figure 1: Thickness of $\mathrm{ZnS}(\mathrm{O}, \mathrm{OH})$ films deposited from 5 different Zn sources versus pK (instability constant). The blue dashed line indicates $\mathrm{Zn}\left[\mathrm{NH}_{3}\right]^{2+}$ complex line, which divides the graph into two regions where (a) $\mathrm{pK}_{\mathrm{Zn}(\mathrm{NH} 3) 2+}>\mathrm{pK}_{\mathrm{Zn}(\mathrm{L}) n}$ and (b) $\mathrm{pK}_{\mathrm{Zn}(\mathrm{NH} 3) 2+}<$ $\mathrm{pK}_{\mathrm{Zn}(\mathrm{L}) n}$.

for the $\mathrm{ZnS}(\mathrm{O}, \mathrm{OH})$ film with smallest clusters, deposited from chemical bath containing $\mathrm{ZnCl}_{2}$.

\subsubsection{The Optical Transmission and Band Gaps of $\mathrm{ZnS}(\mathrm{O}, \mathrm{OH})$}

Films. The results of optical transmission measurements are brought in Figure 3 (squares). In region (a) films transmission decreases with increasing instability constant values and increases after the $\mathrm{Zn}\left[\mathrm{NH}_{3}\right]^{2+}$ complex line in region (b) where $\mathrm{pK}_{\mathrm{Zn}(\mathrm{L}) n}>\mathrm{pK}_{\mathrm{Zn}(\mathrm{NH} 3) 2+}$, probably due to the variations in film thickness.

The optical absorption coefficient $(\alpha)$ was deduced from the transmission and reflectance spectra, using the relation $\alpha$ $=-\ln \left(T_{\text {cor }}\right)$, where as $T_{\text {cor }}$ was calculated $T_{\text {cor }}=T \cdot(1-R)$ from the intensities of the transmitted $(T)$ and reflected $(R)$ lights. A plot of the value of $(\alpha h \nu)^{2}$ against photon energy $(h v)$ shows a straight line portion, and the intercept of this linear portion on the energy axis at $(\alpha h \nu)^{2}$ equal to zero gives the band gap of the material. The values of optical band gap energy in Figure 3 are in the range of $3.6 \mathrm{eV}$, except $3.8 \mathrm{eV}$ for the $\mathrm{ZnS}$ deposited from $\mathrm{Zn}\left(\mathrm{NO}_{3}\right)_{2}$. Similar results are

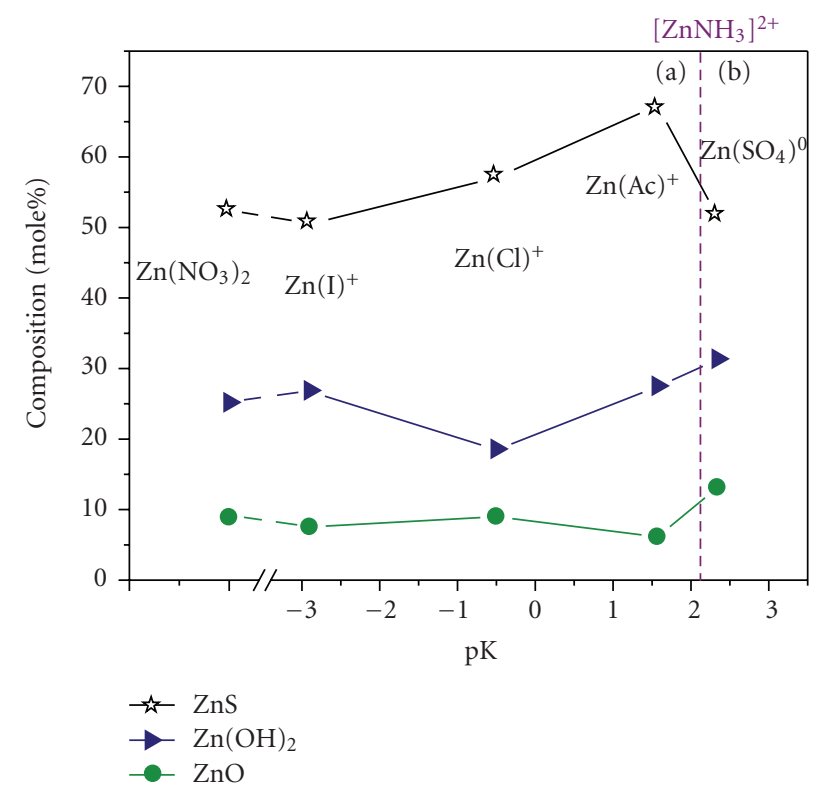

FIgure 2: The composition of $\mathrm{ZnS}(\mathrm{O}, \mathrm{OH})$ films versus $\mathrm{pK}$ (instability constant) of $\mathrm{Zn}$ complexes. The films contain mainly $\mathrm{ZnS}$ (stars), $\mathrm{ZnO}$ (circles), and $\mathrm{Zn}(\mathrm{OH})_{2}$ (triangles).

described in [6] where higher band gap values $(3.75-3.93 \mathrm{eV})$ were gained for CBD-ZnS films deposited from $\mathrm{Zn}\left(\mathrm{NO}_{3}\right)_{2}$ in comparison with those ones from $\mathrm{ZnCl}_{2}$ (3.66-3.78 eV) [6]. The results could be explained with different crystal structure of the $\mathrm{ZnS}$ films from $\mathrm{Zn}\left(\mathrm{NO}_{3}\right)_{2}$ and $\mathrm{ZnCl}_{2}$, since hexagonal $\mathrm{ZnS}$ has larger band gap for (3.67 eV [1], $3.74 \mathrm{eV}$ [17],) than that of cubic $\mathrm{ZnS}$ (3.54 eV [1] and $3.66 \mathrm{eV}$ [17]).

\subsection{The Results of $\mathrm{CuIn}(\mathrm{SSe})_{2}$ and $\mathrm{Cu}_{2}(\mathrm{ZnSn})(\mathrm{SSe})_{4}$ Solar Cells Measurements}

3.3.1. Current-Voltage Characteristics of MGL Solar Cells. The values of open circuit voltages and fill factors were only very slightly affected by the variation of $\mathrm{ZnS}(\mathrm{O}, \mathrm{OH})$ deposition precursor. Current densities of CBD-ZnS/Cu(In)Se $\mathrm{Se}_{2}$ monograin layer solar cells changed with instability constants of Zn-ligand complexes following the same law as that of the growth rate of $\mathrm{ZnS}(\mathrm{O}, \mathrm{OH})$ films (Figure 4). Figure 4 shows 


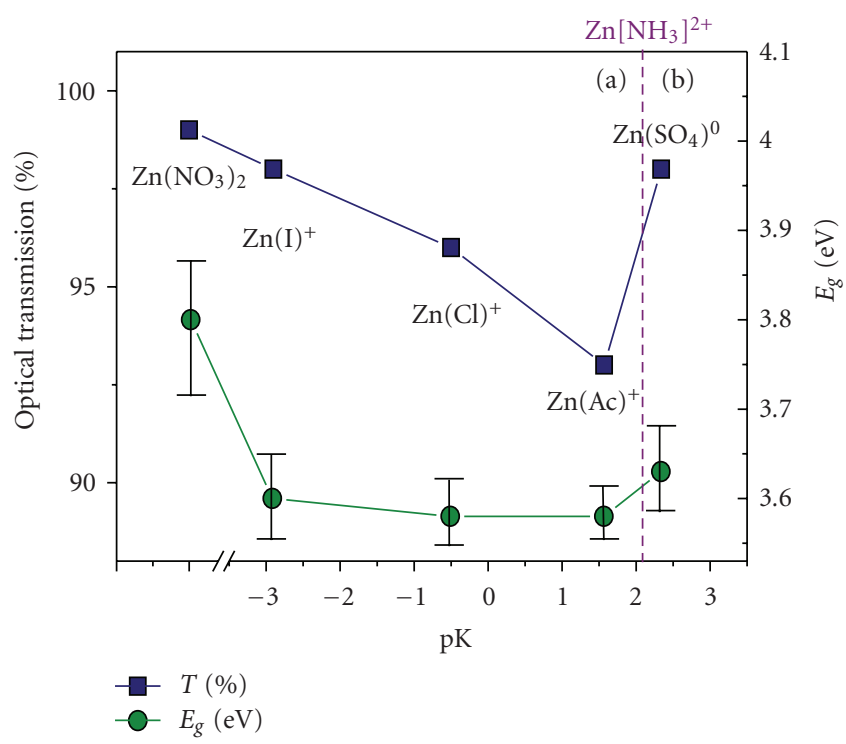

Figure 3: Optical transmission (blue squares) and band gap values (green circles) of $\mathrm{ZnS}(\mathrm{O}, \mathrm{OH})$ films versus instability constant of $\mathrm{Zn}$ complex. The dashed line indicates $\mathrm{Zn}\left[\mathrm{NH}_{3}\right]^{2+}$ complex line.

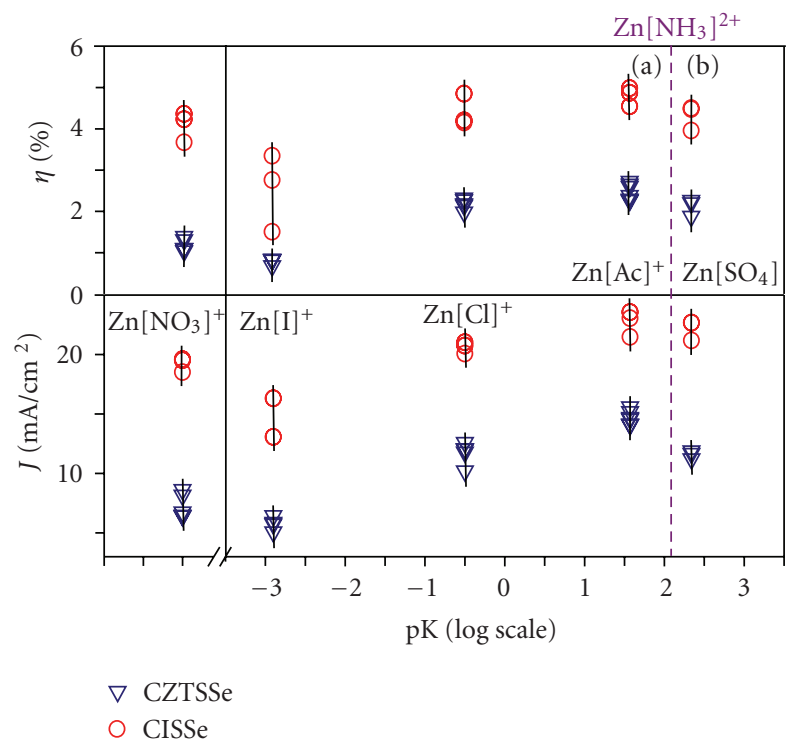

Figure 4: Current densities and efficiencies of CISSe (red) and CZTSSe (blue) MGL solar cells versus Zn-complex instability constant values from various zinc precursors. The dashed line indicates $\mathrm{Zn}\left[\mathrm{NH}_{3}\right]^{2+}$ complex line, which divides the graph to two regions: (a) $\mathrm{pK}_{\mathrm{Zn}(\mathrm{NH} 3) 2+}>\mathrm{pK}_{\mathrm{Zn}(\mathrm{L}) n}$ and (b) $\mathrm{pK}_{\mathrm{Zn}(\mathrm{L}) n}>\mathrm{pK}_{\mathrm{Zn}(\mathrm{NH} 3) 2+}$.

that the CISSe and CZTSSe solar cells with $\mathrm{ZnS}(\mathrm{O}, \mathrm{OH})$ films from $\mathrm{ZnI}_{2}$ with relatively high resistivity and high impurity content in the films have the lowest current densities. The solar cell efficiency curves follow the shape of current density curves (Figure 4). The dependence can be caused by the different thickness of $\mathrm{ZnS}(\mathrm{O}, \mathrm{OH})$ films and the content of $\mathrm{ZnS}$ and impurities in the films. The only exceptions are solar cells with $\mathrm{ZnS}(\mathrm{O}, \mathrm{OH})$ from $\mathrm{Zn}\left(\mathrm{NO}_{3}\right)_{2}$, which have the highest transmission and the largest band gap.
3.4. Discussions. The idea that anions from different zinc salts as $\mathrm{Zn}$ sources in the chemical solution for $\mathrm{ZnS}(\mathrm{O}, \mathrm{OH})$ deposition can act as complexing agents and influence the deposition process was supported by experimental findings. The comparison of values of instability constants (see Table 1) shows that $\mathrm{Zn}\left(\mathrm{SO}_{4}\right)^{0}$ complex is stronger than $\mathrm{Zn}\left(\mathrm{NH}_{3}\right)^{2+}$ complex and the other $\mathrm{Zn}(\mathrm{L})_{1}$ complexes. This fact probably affects $\mathrm{ZnS}(\mathrm{O}, \mathrm{OH})$ films growth in the way that the stronger $\mathrm{Zn}\left(\mathrm{SO}_{4}\right)^{0}$ complex drives (1) left (see Section 3.1), which results in lower ZnS deposition rates and smaller thicknesses. Lower deposition rates increase the time for the deposition process and can result in thinner films with poor coverage on the top of the absorber in solar cells. Poor coverage of the buffer layer can induce shunts in solar cells. From the solar cell results we can see that solar cells with thickest $\mathrm{ZnS}(\mathrm{O}, \mathrm{OH})$ have highest current densities.

On the other hand, $\mathrm{Zn}(\mathrm{OH})_{4}^{2+}$ complex is stronger than $\mathrm{Zn}\left(\mathrm{NH}_{3}\right)^{2+}$ complex and drives (4) right (see Section 3.1), resulting in $\mathrm{Zn}(\mathrm{OH})_{2}$ rich films from $\mathrm{ZnSO}_{4}$ containing chemical bath solution. The variations of $\mathrm{ZnS}, \mathrm{ZnO}$ and $\mathrm{Zn}(\mathrm{OH})_{2}$ content in $\mathrm{CBD}-\mathrm{ZnS}$ change the material optical properties like transmission and also the value of band gap energy. The usage of $\mathrm{ZnS}$ with about $1 \mathrm{eV}$ higher band gap energy $(3.6 \mathrm{eV})$ as buffer material in solar cells instead of usually used CdS $\left(E_{\mathrm{g}}=2.4 \mathrm{eV}\right)$ can result in two effects in solar cell as follows.

(1) More light passes the buffer layer, increasing the light absorption in absorber layer, which increases the current densities of solar cells in the case of $\mathrm{ZnS}$.

(2) There might occur the so-called "spike" in solar cell $p-n$ junction reducing current collection of the solar cell with $\mathrm{ZnS}$ buffer layer [18].

Additionally, $\mathrm{ZnO}$ with band gap energy around $3.2 \mathrm{eV}$ in the buffer material can reduce both effects, opposite to $\mathrm{Zn}(\mathrm{OH})_{2}$ with higher band gap energy value than $\mathrm{ZnS} . \mathrm{Zn}(\mathrm{OH})_{2}$ has generally lower transmission and it can reduce CBD-ZnS transmission, if not dehydrated from the film; therefore, $\mathrm{ZnO}$ is preferable over $\mathrm{Zn}(\mathrm{OH})_{2}$ as a coproduct in CBD-ZnS film. But the lattice constants of $\mathrm{ZnS}$ ( $a=3.8$ hexagonal and 5.4 cubic $\AA$ ) match better with currently used absorber material $(a=5.4-5.8 \AA)$ than $\mathrm{ZnO}(a=3.2 \AA)$; therefore, CBD-ZnS should contain mainly ZnS [19]. As a result, we can find that solar cells with $\mathrm{ZnS}(\mathrm{O}, \mathrm{OH})$ buffer layer deposited from $\mathrm{Zn}(\mathrm{Ac}) 2$, where the highest concentration of $\mathrm{ZnS}$ was found, had highest solar cell current densities and efficiencies.

\section{Conclusions}

The study on the anion effect of the $\mathrm{Zn}$ source for the chemical deposition of $\mathrm{ZnS}(\mathrm{O}, \mathrm{OH})$ films revealed that the growth rate and composition of $\mathrm{ZnS}(\mathrm{O}, \mathrm{OH})$ layer depend on the instability constant value of $\mathrm{Zn}$ complex in chemical bath solution. The $\mathrm{ZnS}(\mathrm{O}, \mathrm{OH})$ film's growth rate and $\mathrm{ZnS}$ concentration in films increased with the increasing value of $\mathrm{Zn}$ precursor's instability constant up to the $\mathrm{Zn}\left[\mathrm{NH}_{3}\right]^{2+}$ complex but decreased after that. The analogous effect of chemical nature of anion was detected for solar cell current 
densities and efficiencies. The highest solar cell current densities and efficiencies were achieved with $\mathrm{ZnS}(\mathrm{O}, \mathrm{OH})$ buffer layers with the highest growth rate and $\mathrm{ZnS}$ content, deposited from $\mathrm{Zn}(\mathrm{Ac})_{2}$. The only exception was solar cell with $\mathrm{ZnS}(\mathrm{O}, \mathrm{OH})$ deposited from $\mathrm{Zn}\left(\mathrm{NO}_{3}\right)_{2}$ containing bath, which results in $\mathrm{ZnS}(\mathrm{O}, \mathrm{OH})$ with the widest band gap (3.8 $\mathrm{eV}$ ) and the highest transmission.

\section{Acknowledgments}

Financial supports of Estonian Ministry of Education and Research by Contract no. SF0140099s08 and Estonian Scientific Foundation under Contract no. 7678 are gratefully acknowledged.

\section{References}

[1] D. R. Lidle, Handbook of Chemistry and Physics, CRC Press, Boca Raton, Fla, USA, 78th edition, 1997-1998.

[2] D. Hariskos, S. Spiering, and M. Powalla, "Buffer layers in $\mathrm{Cu}(\mathrm{In}, \mathrm{Ga}) \mathrm{Se}_{2}$ solar cells and modules," Thin Solid Films, vol. 480-481, pp. 99-109, 2005.

[3] I. Repins, M. A. Contreras, B. Egaas, et al., "19.9\%-efficient $\mathrm{ZnO} / \mathrm{CdS} / \mathrm{CuInGaSe}{ }^{2}$ solar cell with $81.2 \%$ fill factor," Progress in Photovoltaics: Research and Applications, vol. 16, no. 3, pp. 235-239, 2008.

[4] T. Nakada, M. Mizutani, Y. Hagiwara, and A. Kunioka, "Highefficiency $\mathrm{Cu}(\mathrm{In}, \mathrm{Ga}) \mathrm{Se}_{2}$ thin-film solar cells with a CBD-ZnS buffer layer," Solar Energy Materials and Solar Cells, vol. 67, no. $1-4$, pp. 255-260, 2001.

[5] A. Eshuis, G. R. A. van Elderen, and C. A. J. Koning, "A descriptive model for the homogeneous precipitation of zinc sulfide from acidic zinc salt solutions," Colloids and Surfaces A, vol. 151, no. 3, pp. 505-512, 1999.

[6] A. Antony, K. V. Murali, R. Manoj, and M. K. Jayaraj, "The effect of the $\mathrm{pH}$ value on the growth and properties of chemical-bath-deposited ZnS thin films," Materials Chemistry and Physics, vol. 90, no. 1, pp. 106-110, 2005.

[7] Y. Zhao, J.-M. Hong, and J.-J. Zhu, "Microwave-assisted selfassembled ZnS nanoballs," Journal of Crystal Growth, vol. 270, no. 3-4, pp. 438-445, 2004.

[8] H. Khallaf, I. O. Oladeji, G. Chai, and L. Chow, "Characterization of CdS thin films grown by chemical bath deposition using four different cadmium sources," Thin Solid Films, vol. 516, no. 21, pp. 7306-7312, 2008.

[9] M. Altosaar, K. Ernits, J. Krustok, T. Varema, J. Raudoja, and E. Mellikov, "Comparison of CdS films deposited from chemical baths containing different doping impurities," Thin Solid Films, vol. 480-481, pp. 147-150, 2005.

[10] R. Ortega-Borges and D. Lincot, "Mechanism of chemical bath deposition of cadmium sulfide thin films in the ammoniathiourea system," Journal of the Electrochemical Society, vol. 140, no. 12, pp. 3464-3473, 1993.

[11] E. Bacaksiz, M. Parlak, M. Tomakin, A. Özcelik, M. Karakiz, and M. Altunbas, "The effects of zinc nitrate, zinc acetate and zinc chloride precursors on investigation of structural and optical properties of $\mathrm{ZnO}$ thin films," Journal of Alloys and Compounds, vol. 466, no. 1-2, pp. 447-450, 2008.

[12] M. Altosaar, A. Jagomägi, M. Kauk, et al., "Monograin layer solar cells," Thin Solid Films, vol. 431-432, pp. 466-469, 2003.

[13] M. Altosaar, J. Raudoja, K. Timmo, et al., " $\mathrm{Cu}_{2} \mathrm{Zn}_{1-x} \mathrm{Cd}_{x} \mathrm{Sn}\left(\mathrm{Se}_{1-y} \mathrm{~S}_{y}\right)_{4}$ solid solutions as absorber materials for solar cells," Physica Status Solidi A, vol. 205, no. 1, pp. 167-170, 2008.

[14] Handbook of Chemistry II, Izdatelstvo Himia, Moscow, Russia, 1965.

[15] J. J. Loure, Handbook of Analythical Chemistry, Izdatelstvo Himia, Moscow, Russia, 1965.

[16] K. Ernits, K. Muska, M. Kauk, et al., "Chemical bath deposition of ZnS films using different Zn-salts," in Proceedings of the E-MRS Spring Meeting Symposium, Strasbourg, France, June 2009, poster BP4-10.

[17] Physics of $A^{I I} B^{V I}$ Compounds, Nauka, Moscow, Russia, 1986.

[18] T. Minemoto, T. Matsui, H. Takakura, et al., "Theoretical analysis of the effect of conduction band offset of window/CIS layers on performance of CIS solar cells using device simulation," Solar Energy Materials and Solar Cells, vol. 67, no. 1-4, pp. 83-88, 2001.

[19] K. Ernits, Study of $\operatorname{In}_{2} S_{3}$ and $Z n S$ thin films deposited by ultrasonic spray pyrolysis and chemical deposition, dissertation, Tallinn University of Technology, Tallinn, Estonia, 2009. 

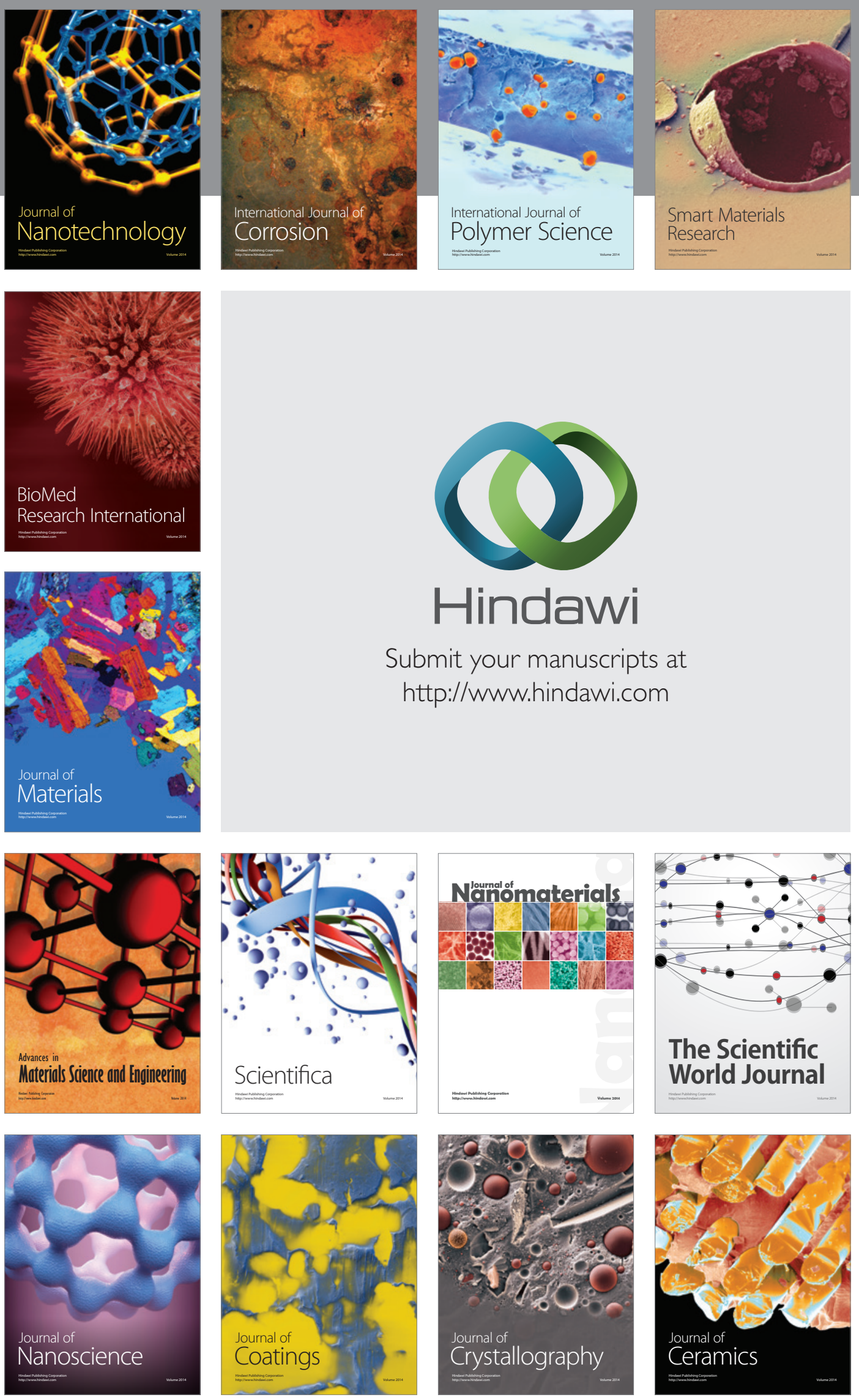

The Scientific World Journal

Submit your manuscripts at

http://www.hindawi.com

\section{World Journal}

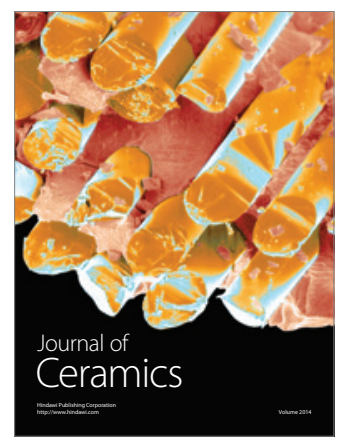

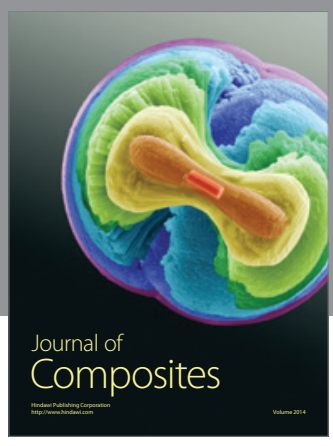
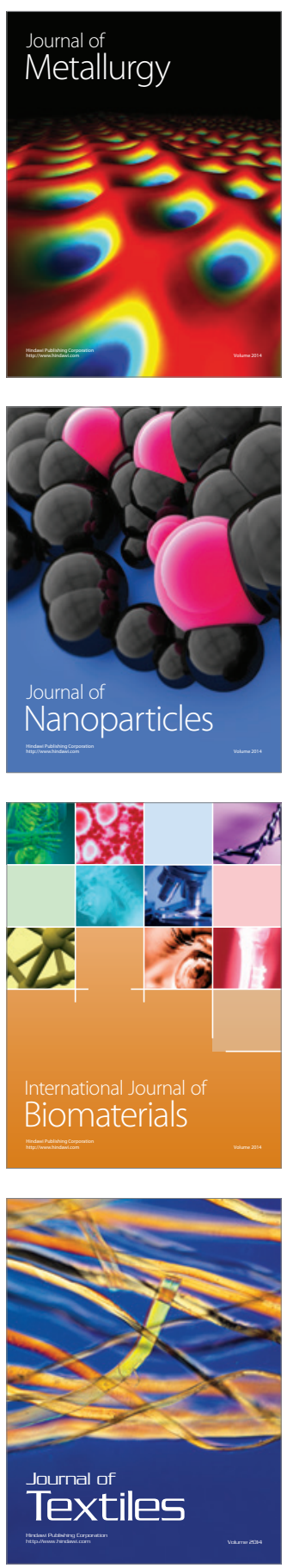